\title{
PENYELESAIAN SENGKETA WARIS \\ DI LUAR PENGADILAN AGAMA \\ (Studi Kasus di Desa Ngadi Kecamatan Mojo Kabupaten Kediri) \\ Fachrodin $^{1}$ \\ fachrodin983@gmail.com
}

\begin{abstract}
Abstrak
Fenomena yang berkembang dalam masyarakat masih banyaknya proses pembagian harta waris yang tidak diselesaikan melalui Pengadilan Agama, di sebagian Desa wilayah Kabupaten Kediri, terdapat sebuah desa yang bernama Desa Ngadi, di Desa itu terjadi sebuah proses penyelesaian sengketa waris yang dilakukan di kantor desa. Setiap terjadi sebuah sengketa waris selalu berkonsultasi dengan aparat desa setempat, dan dalam praktek pembagian harta waris banyak masyarakat yang menginginkan pembagiannya satu banding satu, atau berdasarkan perdamaian yang dikenal dengan islah, penyelesaian sengketa waris tersebut dicatat dihadapan dan di buat oleh aparat desa. Tujuan penelitian ini adalah: (1) Untuk mengupas lebih dalam proses penyelesaian sengketa waris dengan tujuan mendapatkan solusi yang lebih baik dari kesepakatan yang telah di dapat dari para pihak di hadapan aparatur Desa Ngadi Kecamatan Mojo Kabupaten Kediri. (2) Untuk mendapatkan realita hukum latar belakang permasalahan dan sebagai bahan anti tesis dengan pasal-pasal waris yang ada di Kompilasi Hukum Islam dan hukum secara umum. Kesimpulan hasil penelitian ini adalah: (1) Proses penyelesaian sengketa waris di desa Ngadi Kecamatan Mojo kabupaten Kediri dilakukan dengan cara musyawarah keluarga yang berlanjut sampai ke kantor desa yang di hadiri oleh pamong desa dan kyai setempat untuk mendapat saran hukum dan petunjuk administratif pertanahan. Sedangkan prakteknya penyelesaian sengketa waris di luar Pengadilan Agama yang terjadi di Desa Ngadi dilakukan secara mufakat yang dihadiri oleh para ahli waris, sekretaris desa, kaur pemerintahan, kaur umum, kepala dusun dan seorang kyai. (2) Yang melatar belakangi penyelesaian sengketa waris yang dilakukan di Desa Ngadi Kecamatan Mojo Kabupaten Kediri adalah disebabkan karena adanya beberapa faktor, antara lain: faktor benturan dengan aturan hukum positif, faktor ekonomi, faktor psikologi, faktor sosial dan juga faktor tradisi dan agama yang masih berkembang kuat di masyarakat.
\end{abstract}

Kata Kunci: Sengketa Waris, Pengadilan Agama.

\footnotetext{
${ }^{1}$ Institut Agama Islam Hasanuddin Pare Kediri
} 


\begin{abstract}
The phenomenon that develops in society is that there are still many inheritance distribution processes that are not resolved through the Religious Courts, in some villages in the Kediri Regency, there is a village called Ngadi Village, in that village there is a process of inheritance dispute resolution which is carried out at the village office. Every time there is an inheritance dispute, they always consult with the local village apparatus, and in the practice of distributing inheritance, many people want the distribution one to one, or based on peace, known as islah, the settlement of the inheritance dispute is recorded in front of and made by the village apparatus. The objectives of this study are: (1) To explore more deeply the process of resolving inheritance disputes with the aim of getting a better solution from the agreement that has been obtained from the parties in front of the Ngadi Village apparatus, Mojo District, Kediri Regency. (2) To obtain the legal reality of the background of the problem and as an anti-thesis material with the inheritance articles in the Compilation of Islamic Law and law in general. The conclusions of this research are: (1) The process of settlement of inheritance disputes in Ngadi village, Mojo district, Kediri district is carried out by means of family deliberation which continues to the village office which is attended by village officials and local kyai to get legal advice and land administrative instructions. Meanwhile, the practice of resolving inheritance disputes outside the Religious Courts that occurred in Ngadi Village was carried out by consensus which was attended by the heirs, village secretaries, government heads, general heads, hamlet heads and a kyai. (2) The background of the settlement of inheritance disputes in Ngadi Village, Mojo District, Kediri Regency is due to several factors, including: conflict factors with positive legal rules, economic factors, psychological factors, social factors as well as traditional and religious factors that still growing strong in society.
\end{abstract}

Keywords: Inheritance Dispute, Religious Court.

\title{
A. Pendahuluan
}

Agama Islam yang dibawa oleh Nabi Muhammad SAW sudah mengatur secara lengkap dan sempurna segala aspek kehidupan untuk keselamatan dunia dan akhirat. Salah satu syariat yang diatur dalam ajaran Islam tentang hukum waris, yakni pemindahan harta warisan kepada ahli waris yang berhak menerimanya. ${ }^{2}$

Dalam penjelasan pasal 49 huruf b UU No. 3 Tahun 2006 dijelaskan bahwa yang dimaksud dengan waris adalah penentuan siapa-siapa yang menjadi ahli waris, penentuan mengenai harta peninggalan, penentuan bagian masing-masing ahli waris dan pelaksanaan pembagian harta peninggalan tersebut serta penetapan pengadilan atas

\footnotetext{
${ }^{2}$ Mohammad Ali Ash-Shabuni, "Pembagian Warisan Menurut Islam", Gema Insani Press 1996, http: //Koleksi Pengetahuan. Wordpress.com, 19 Februari 2010, Diakses Tanggal 02 Maret 2012.
} 
permohonan seseorang tentang penentuan siapa yang menjadi ahli waris, penentuan bagian masing- masing ahli waris. ${ }^{3}$

Membicarakan tentang masalah sistem peraturan perundangan di Indonesia tidak terlepas dari persoalan tentang terbentuknya Undang-undang Kompilasi Hukum Islam, yang pada dasarnya membicarakan sebagian kecil dari Hukum Islam di Indonesia. Hukum waris menurut Kompilasi Hukum Islam pada Pasal 171 (a) yaitu hukum yang mengatur tentang pemindahan hak kepemilikan harta peninggalan pewaris, menentukan siapa yang berhak menjadi ahli waris dan berapa bagiannya masing-masing. Tata cara pembagian harta warisan dalam Islam telah diatur dengan sebaik-baiknya. Alqur'an menjelaskan dan merinci secara detail hukum-hukum yang berkaitan dengan hak kewarisan tanpa mengabaikan hak seorang pun. Pembagian masing- masing ahli waris baik itu laki-laki maupun perempuan telah ada ketentuannya dalam Alqur'an. ${ }^{4}$

Pembagian harta warisan dapat juga dilakukan dengan cara bagi rata, artinya masing-masing ahli waris mendapat bagian yang sama dari harta warisan tanpa memandang apakah ahli warisnya itu laki-laki atau perempuan dengan jalan berdamai berdasarkan kesepakatan bersama antara ahli waris sebagaimana disebutkan pada ketentuan Pasal 183 Kompilasi Hukum Islam.

Fenomena yang berkembang dalam masyarakat masih banyaknya proses pembagian harta waris yang tidak diselesaikan melalui Pengadilan Agama, di sebagian Desa wilayah Kabupaten Kediri, terdapat sebuah desa yang bernama Desa Ngadi, di Desa itu terjadi sebuah proses penyelesaian sengketa waris yang dilakukan di kantor desa. Setiap terjadi sebuah sengketa waris selalu berkonsultasi dengan aparat desa setempat, dan dalam praktek pembagian harta waris banyak masyarakat yang menginginkan pembagiannya satu banding satu, atau berdasarkan perdamaian (musyawarah) yang dikenal dengan islah, penyelesaian sengketa waris tersebut dicatat dihadapan dan di buat oleh aparat desa. tetapi cara ini belum bisa menjamin bahwa sengketa tersebut tidak akan ada masalah lagi dikemudian hari, karena belum adanya surat yang kuat dari Pengadilan Agama, jika ahli waris yang awalnya sepakat ternyata akhirnya mengingkari akan penyelesaian pembagian harta waris tersebut, maka

\footnotetext{
${ }^{3}$ UU No. 3 Tahun 2006 Tentang Perubahan UU No. 7/1989 Tentang Pengadilan Agama.

${ }^{4}$ Abdurrahman, Kompilasi Hukum Islam, (Jakarta: Pressindo, 1992), 56.
} 
timbullah rasa kecemburuan di antara ahli waris. Akibat dari hal tersebut proses pengalihan hak tanah menjadi tersendat dan membutuhkan waktu yang panjang. ${ }^{5}$

Namun demikian, mengapa masyarakat desa Ngadi setiap terjadi sebuah sengketa waris dalam penyelesaiannya masih saja melalui aparat desa setempat, apakah dengan langkah tersebut dapat mewujudkan harapan bahwa tak akan ada lagi sisa permasalahan yang kemungkinan akan muncul di kemudian hari. Padahal Negara Republik Indonesia yang kehidupan rakyatnya masih bersifat agraris, di mana perekonomiannya masih bertumpu pada ekonomi pertanian, maka diperlukan aturanaturan hukum yang mengatur tentang status kepemilikan tanah. Indonesia memiliki ketentuan khusus yang mengatur tentang pertanahan sebagaimana disebutkan dalam Undang-Undang No. 5 Tahun 1960 tentang Undang-Undang Pokok Agraria yang kemudian disebut UUPA, yang dinyatakan berlaku sejak tanggal 24 September 1960. ${ }^{6}$

Dari konteks penelitian di atas dapat di pahami bahwa betapa pentingnya penyelesaian sengketa waris di Pengadilan Agama. Dengan demikian telah dipaparkan penyelesaian sengketa waris menurut hukum dan undang-undang serta fenomena sengketa waris yang berkembang dalam masyarakat Desa Ngadi. Tujuan penelitian ini adalah: (1) Untuk mengupas lebih dalam proses penyelesaian sengketa waris dengan tujuan mendapatkan solusi yang lebih baik dari kesepakatan yang telah di dapat dari para pihak di hadapan aparatur Desa Ngadi Kecamatan Mojo Kabupaten Kediri. (2) Untuk mendapatkan realita hukum latar belakang permasalahan dan sebagai bahan anti tesis dengan pasal-pasal waris yang ada di Kompilasi Hukum Islam dan hukum secara umum.

\section{B. Metode Penelitian}

\section{Pendekatan dan Jenis Penelitian}

Dalam penelitian ini penulis menggunakan pendekatan kualitatif. Pendekatan kualitatif lebih menekankan analisisnya pada proses penyimpulan deduktif dan induktif serta pada analisis terhadap dinamika hubungan antar fenomena yang diamati dengan menggunakan logika ilmiah. ${ }^{7}$ Jenis penelitian ini adalah penelitian lapangan, yaitu

\footnotetext{
${ }^{5}$ Siti Umayyah, Kepala Desa Ngadi, Kediri.

${ }^{6}$ Undang-Undang No. 5 Tahun 1960 tentang Undang-Undang Pokok Agraria. Hal. 1

${ }^{7}$ Saifuddin Azwar, Metode Peneltian (Yogyakarta: Pustaka Pelajar Offset, 2001), 5
} 
mempelajari secara intensif latar belakang, status terakhir dan interaksi lingkungan yang terjadi pada suatu satuan sosial seperti individu, kelompok, lembaga atau komunitas. ${ }^{8}$

Pendekatan ini memiliki ciri-ciri antara lain: (1) desain penelitian bersifat lentur dan terbuka, (2) data penelitian diambil dengan latar alami (natural setting), (3) data yang dikumpulkan berupa data deskriptif dan reflektif, (4) lebih mementingkan proses daripada hasil, (5) sangat mementingkan makna (meaning), (6) sampling dilakukan secara internal yang didasarkan pada subjek yang memiliki informasi yang paling representatif, (7) analisis data dilakukan pada saat dan setelah pengumpulan data, (8) kesimpulan dari penelitian kualitatif dikonfirmasikan dengan informasi. ${ }^{9}$

\section{Kehadiran Peneliti}

Kehadiran peneliti di sini sangat penting, karena dalam penelitian ini peneliti bertindak sebagai instrument sekaligus pengumpul data. Dalam penelitian kualitatif, peneliti sendiri atau dengan bantuan orang lain merupakan alat pengumpul data utama. ${ }^{10}$

Karena peneliti merupakan salah satu instrumen kunci dalam menangkap makna dan sekaligus sebagai alat pengumpul data dalam pengumpulan data yaitu mengenai observasi. Peneliti bertindak sebagai pengamat partisipasi dan kehadiran peneliti diketahui statusnya oleh obyek/informan. Dalam hal ini peneliti berbaur secara langsung dengan masyarakat Desa Ngadi dengan tujuan ingin mengetahui secara rinci tentang penyelesaian sengketa waris yang dilakukan oleh masyarakat desa Ngadi Kecamatan Mojo Kabupaten Kediri.

\section{Lokasi Penelitian}

Lokasi yang dipilih dalam penelitian ini adalah Desa Ngadi Kecamatan Mojo Kabupaten Kediri. Lokasi tersebut merupakan sebuah desa yang semua penduduknya beragama Islam. Maka dari itu penulis ingin mengetahui apakah masyarakat yang mayoritas beragama Islam mengetahui tentang bagaimana cara dalam menyelesaikan sengketa waris.terutama dalam permasalahan pembagian harta waris.

\footnotetext{
${ }^{8}$ Ibid., 8.

9 Ahmad Sonhaji, Teknik Penulisan Laporan Penelitian Kualitatif dalam Penelitian Kualitatif dalam Ilmu-Ilmu Sosial dan keagamaan (Malang: Kalimasada Pers, 1996), 108.

${ }^{10}$ Saifuddin Azwar, Metode Peneltian (Yogyakarta: Pustaka Pelajar Offset, 2001), 26.
} 


\section{Sumber Data}

Ada dua sumber data yang penulis gunakan dalam penelitian ini, yaitu data primer dan sekunder. Data primer diperoleh dari sumber primer, yakni peneliti atau penulis secara langsung melakukan observasi atau penyaksian kejadian yang dituliskan. ${ }^{11}$ Data dalam penelitian ini adalah semua data atau informasi yang diperoleh dari para informan yang dianggap paling mengetahui secara rinci dan jelas mengenai fokus penelitian yaitu penyelesaian sengketa waris di luar Pengadilan Agama. Selain dari informan, data juga diperoleh dari hasil dokumentasi yang menunjang.

Sedangkan data sekunder diperoleh dari hasil observasi orang lain yang satu kali atau lebih dan telah lepas dari kejadian aslinya. ${ }^{12}$ Dalam penelitian ini yang dimaksud sumber data sekunder yaitu dokumentasi yang terdiri dari arsip-arsip, dokumendokumen, dan berkas-berkas perkara yang ditimbulkan akibat dari penyelesaian sengketa waris yang dilakukan di Desa Ngadi.

\section{Metode Pengumpulan Data}

Untuk memperoleh data-data yang objektif dan sesuai dengan realita, maka dalam penelitian ini penulis mengumpulkan data dengan menggunakan metode sebagai berikut:

a. Metode Observasi

Observasi merupakan pengamatan secara langsung yang dilakukan oleh peneliti terhadap masalah-masalah atau fenomena yang dihadapi. Dalam kegiatan ini, peneliti melakukan pencatatan secara sistematis dan memberikan penilaian.

Observasi di sini bersifat partisipatif, yakni peneliti terlibat dengan kegiatan seharai-hari, orang yang sedang diamati atau yang dianggap sebagai sumber data penelitian, ${ }^{13}$ kegiatan observasi tersebut tidak hanya dilakukan terhadap kenyataan kenyataan yang terlihat, tetapi juga terhadap kenyataan yang terdengar. ${ }^{14}$ Metode ini penulis gunakan untuk menghimpun data tentang situasi dan kondisi masyarakat Desa Ngadi Kecamatan Mojo Kabupaten Kediri, secara khusus untuk mengumpulkan data

\footnotetext{
${ }^{11}$ Ahmad Taufiq Weldan, Dimyati Huda, Metodologi Studi Islam (Malang: Bayumedia Publishing, 2004), 18.

12 Ibid,. 18.

13 Sugiono, Memahami Penelitian Kualitatif (Bandung: Alfabeta Press, 2005), 64.

14 Burhan Bungin, Analisis Data Penelitian Kualitatif (Jakarta: PT. Raja Grafindo Persada, 2003), 66.
} 
penyelesaian sengketa waris di masyarakat Desa Ngadi. Peneliti juga melibatkan langsung untuk mengadakan pengamatan dan pencatatan kegiatan serta aktifitas objek.

b. Metode Interview/Wawancara

Interview yang sering juga disebut dengan wawancara atau kuisioner lisan, adalah sebuah dialog yang dilakukan oleh pewawancara (interviewer) untuk memperoleh informasi dari terwawancara (interviewe). ${ }^{15}$ Metode interview adalah metode pengumpulan data melalui percakapan yang bertujuan mendapatkan data yang diperlukan, baik antara dua orang atau lebih dan peneliti sebagai pihak yang mengarahkan arah pembicaraan.

Wawancara dalam penelitian ini dilakukan kepada kepala desa, tokoh agama, sesepuh desa, dan masyarakat setempat. Metode ini digunakan untuk mengetahui bagaimana penyelesaian sengketa waris dalam pembagian harta warisan yang dilakukan di Desa Ngadi Kecamatan Mojo Kabupaten Kediri. Selengkapnya para informan tersebut adalah sebagai berikut: Ibu Siti Umayah (selaku Kepala Desa Ngadi), Bapak H.M. Ismunandar (selaku Sekretaris Desa Ngadi), Bapak Imam Ahmad dan Bapak Samsul Huda (selaku tokoh masyarakat Desa Ngadi), serta Ibu H. Sarmini, dan Ibu Sarmilah sebagai pelaku sengketa waris tersebut.

c. Metode Dokumentasi

Dokumen merupakan catatan peristiwa yang sudah berlalu. Dokumen bisa berbentuk tulisan, gambar atau karya-karya monumental dari seseorang. ${ }^{16}$ Dalam hal ini dokumentasi dilakukan untuk memperoleh data tentang:

1) Profil dan sejarah singkat tentang Desa Ngadi Kecamatan Mojo Kabupaten Kediri.

2) Data tenaga edukatif (kepala desa) dan perangkat Desa Ngadi Kecamatan Mojo Kabupaten Kediri.

Data di atas digunakan untuk mengetahui kondisi masyarakat Desa Ngadi meliputi struktur perangkat desa, kondisi geografis, kondisi sosial kemasyarakatan, keagaman, serta kondisi perekonomian masyarakat Desa Ngadi Kecamatan Mojo Kabupaten Kediri.. Sehingga memudahkan peneliti untuk menyesuaikan diri dengan masyarakat Desa Ngadi terkait keinginan penulis untuk melakukan penelitian di Desa tersebut. Dengan metode dokumentasi ini, penulis dapat mengumpulkan data-data yang

\footnotetext{
${ }^{15}$ Suharsimi Arikunto, Prosedur Penelitian (Jakarta: Rineka Cipta, 1996), 144.

${ }^{16}$ Sugiono, Memahami Penelitian Kualitatif (Bandung: Alfabeta Press, 2005), 82.
} 
berupa dokumen-dokumen tentang penyelesaian sengketa waris di Desa Ngadi Kecamatan Mojo Kabupaten Kediri.

\section{Analisis Data}

Di bagian ini penulis akan menguraikan tentang cara menganalisis data. Analisis data disini merupakan "upaya mencari dan menata catatan hasil observasi dan wawancara serta data lainnya untuk meningkatkan pemahaman peneliti tentang kasus yang diteliti dan menyajikan sebagai temuan bagi orang lain, untuk meningkatkan pemahaman tersebut analisis perlu dilanjutkan dengan mencari makna". ${ }^{17}$ Dalam menganalisis data yang telah dihimpun penulis menggunakan dua metode, yaitu:

a. Analisa Deduktif

Yaitu analisa data dengan cara menerangkan beberapa data yang bersifat umum yang kemudian diambil kesimpulan-kesimpulan yang bersifat khusus dari data tersebut. Berfikir deduktif adalah proses pendekatan yang berangkat dari kebenaran umum mengenai suatu fenomena (teori) dan menggeneralisasikan kebenaran tersebut pada suatu peristiwa atau data tertentu yang berciri sama dengan fenomena yang bersangkutan (prediksi). Dengan kata lain, deduksi berarti menyimpulkan hubungan yang tadinya tidak tampak, berdasarkan generalisasi yang sudah ada. ${ }^{18}$

b. Analisa Induktif

Berfikir induktif adalah proses logika yang berangkat dari sebuah empirik lewat observasi menuju kepada suatu teori. Dengan kata lain, induksi adalah proses pengorganisasian fakta-fakta atau hasil-hasil pengamatan yang terpisah-pisah menjadi suatu tingkatan hubungan atau suatu generalisasi. ${ }^{19}$

Dengan metode ini, peneliti berusaha mempelajari serta menganalisis beberapa data untuk kemudian dibangun suatu sintesis yang berupa kesimpulan konseptional yang bersifat umum. Dari sekian data yang telah didapat, peneliti akan mengurutkan data-data tersbut, mengelompokkan serta mangategorikannya bersamaan dengan teori yang telah ada.

17 Noeng Muhadjir, Metodologi Penelitian Kualitatif (Yogyakarta: Rake Sarasin, 1996), 104.

18 Saifuddin Azwar, Metode Peneltian (Yogyakarta: Pustaka Pelajar Offset, 2001), 40.

${ }^{19}$ Ibid.41. 


\section{Pengecekan Keabsahan Data}

Dalam pemeriksanaan keabsahan data yang diperoleh dalam penelitian ini, yaitu menggunakan uji kredibilitas data atau kepercayaan terhadap data hasil penelitian kualitatif antara lain dilakukan dengan cara:

a. Keikutsertaan Peneliti Dan Ketekunan Pengamatan

Dalam hal ini, peneliti melakukan kegiatan pengamatan dengan terjun ke dalam lokasi guna mendeteksi atau mempelajari serta meguji informasi yang diperoleh. Selain itu, peneliti juga melakukan ketekunan pengamatan yang bermaksud menemukan ciriciri dan unsur-unsur dalam situasi yang sangat relevan dengan persoalan atau isu yang sedang dicari dan kemudian memusatkan diri pada hal-hal yang sedang diteliti secara rinci. Hal itu berarti bahwa peneliti akan mengadakan pengamatan dengan teliti dan rinci secara berkesinambungan terhadap permasalahan yang diteliti, sehingga peneliti akan lebih memahami permasalahan serta situasi yang relevan dengan persoalan tersebut.

b. Triangulasi

Triangulasi adalah teknik pemeriksaan keabsahan data yang memanfaatkan sesuatu yang lain di luar data itu untuk keperluan pengecekan atau sebagai pembanding terhadap data itu. ${ }^{20}$ Peneliti akan meggunakan metode triangulasi ini sebagai bagian dari metode pengecekan terhadap keabsahan data-data yang telah didapat. Teknik triangulasi dalam penelitian ini menggunakan dua macam yaitu:

Pertama: triangulasi dengan sumber, yaitu peneliti membandingkan perolehan data pada teknik yang berbeda dalam fenomena yang sama

Kedua: triangulasi dengan metode, yakni peneliti akan membandingkan perolehan data dari teknik pengumpulan data yang sama dengan sumber yang berbeda.

\section{Tahap-Tahap Penelitian}

Dalam sebuah penelitian, tidaklah lepas dari perencanaan serta penjadwalan waktu penelitian yang akan dilakukan secara bertahap. Dalam penelitian ini, peneliti mebaginya menjadi empat tahapan. Keempat tahapan tersebut yaitu:

a. Tahap sebelum terjun ke lapangan yang meliputi kegiatan:

1) Menyusun proposal penelitian

\footnotetext{
${ }^{20}$ Lexi J. Moleong, Metode Penelitian Kualitatif (Bandung: PT Remaja Rosda Karya Offset, 2002), 178.
} 
2) Seminar proposal

3) Konsultasi penelitian kepada pembimbing

4) Mengurus surat ijin penelitian

5) Menyiapkan perlengkapan penelitian

6) Menghubungi lokasi penelitian

b. Tahap pekerjaan lapangan yang meliputi kegiatan:

1) Pengumpulan data atau informasi yang terkait dengan fokus penelitian

2) Pencatatan data yang telah dikumpulkan

c. Tahap analisis data yang meliputi:

1) Pengorganisasian data dan informasi yang diperoleh menjadi rekonstruksi unit study yang koheren dan terpadu

2) Pengkategorian data

3) Penemuan hal-hal penting dari data penelitian

4) Pengecekan keabsahan data

d. Tahap penulisan laporan penelitian yang meliputi kegiatan:

1) Menyusun hasil penelitian

2) Perbaikan hasil penelitian

\section{Hasil Penelitian dan Pembahasan}

Di Desa Ngadi Kecamatan Mojo Kabupaten Kediri dalam memahami sistem penyelesaian sengketa waris di luar Pengadilan Agama sangat bervariasi. Dalam praktiknya para penduduk di sana lebih menganut pada sistem penyelesaian di luar Pengadilan yang sudah menjadi kebiasaan leluhurnya terdahulu yang dilakukan dengan cara musyawarah. Di sisi lain, hukum kewarisan sebagaimana yang diatur dalam hukum Islam dan peraturan pemerintah tenteng penyelesaian yang dilakukan di Pengadilan Agama seakan terabaikan dan jarang terlaksana sebagaiman mestinya. ${ }^{21}$ Seperti yang disampaikan oleh kepala Desa setempat, yaitu ibu Siti Umayah ketika diwawancarai oleh penulis dalam rangka mencari informasi awal terkait penelitian ini, "memang di Desa Ngadi tersebut dalam pelaksanaan penyelesaian sengketa waris masih cenderung meminta bantuan aparat Desa dan pemuka agama setempat dan jarang yang mempraktikkan hukum waris secara murni seperti yang diajarkan agama Islam. ${ }^{22}$

\footnotetext{
${ }^{21}$ Observasi, Di Kantor Desa Ngadi, Kediri, 25 Mei 2012.

22.Siti Umayah, Kepala desa Ngadi, Kediri, 25 Mei 2012.
} 


\section{Pemahaman Masyarakat Desa Ngadi Kecamatan Mojo Kabupaten Kediri Tentang Penyelesaian Sengketa Waris Di Luar Pengadilan.}

Pengetahuan dan pemahaman masyarakat mengenai pentingnya penyelesaian sengkata waris sebagai bagian dari ajaran agama Islam merupakan salah satu indikator kesadaran masyarakat terhadap hukum kewarisan Islam bagi masyarakat muslim pada umumnya dan khususnya masyarakat muslim di Desa Ngadi. Pemahaman masyarakat tentang sistem penyelesaian sengketa waris sangat bervariasi. Untuk itu, perlu diklasifikasikan terlebih dahulu jumlah responden. Dalam hal ini peneliti menggunakan 5 (lima) responden untuk diwawancarai terkait dengan pemahaman mereka terhadap penyelesaian sengketa waris di luar Pengadilan Agama yang dilakukan di Desa Ngadi, di antaranya:

a. Siti Umayah (Kades)

b. H.M.Ismunandar (Sekdes)

c. Imama Ahmad, Samsul Huda (Pemuka Agama)

d. Karnati, Sarmini, Sarmilah, Moh.Ajam (almarhum), (Ahli waris)

e. Wiwin Agus S, Didik May S, Trianing Dwi Astuti, Ida Nur Hayati, Bambang S (Ahli waris)

Bahwa penyelesaian sengkata waris di luar Pengadila Agama adalah penyelesaian pembagian harta waris yang di lakukan oleh pihak yang bersangkutan melalui musyawarah keluarga dengan mengumpulkan semua ahli waris yang berkepentingan hingga yang bersangkutan mengetahui bagiannya masing-masing tanpa melalui proses Pengadilan Agama. Dan putusan tersebut sudah dianggap sah, karena semua pihak sudah menyetujuinya, lalu dilakukan penandatanganan surat keterangan waris di atas materai.

Memang kalau dilihat dari administratif penyelesaian sengketa waris di luar pengadilan lebih mudah dan tidak terlalu merepotkan bagi semua pihak kususnya ahli waris, alhamdulillah sampai saat ini permasalahan sengketa waris yang pernah di tangani melalui musawarah yang di bantu oleh pamong desa tidak ada masalah yang muncul, walaupun ada satu dua ahli waris yang tidak puas dengan keputusan yang sudah di sepakati bersama, namun tidak sampai berlanjut ke Pengadilan Agama.

Penyelesaian waris di luar Pengadilan Agama adalah penyelesaian yang dilakukan dengan cara musyawarah, dan itu sah, walaupun tidak datang ke pengadilan 
agama, sebab dari pihak ahli waris sudah sepakat dan di tandatangani bersama, dan di saksikan di catat oleh pamong desa dan pemuka agama.

Bahwa penyelesaian sengketa waris di luar Pengadilan Agama adalah pembagian harta waris berupa barang bergerak atau barang tidak bergerak yang dilakukan oleh para pihak ahli waris untuk mendapatkan haknya masing-masing ahli waris tanpa harus ke Pangadilan Agama dalam arti mereka melakukan dengan jalan musyawarah.

Penyelesaian sengketa waris yang di lakukan dengan cara musyawarah yang dilanjutkan ke Kantor Desa setempat di saksikan dan dicatat oleh aparat dan pemuka agama setempat sehingga menghasilkan keputusan yang sudah di sepakati bersama dan tidak sampai ke Pengadilan Agama.

Bahwa praktek seperti ini sudah berjalan sejak lama, akan tetapi cara tersebut kurang tepat, karena negara kita adalah negara hukum, jadi dalam penyelesaian sengketa waris harus di lakukan di pengadilan agama tidak di lakukan di kantor desa, sebab kantor desa bukan tempat penyelesaian sengketa waris, kalaupun ada yang di selesaikan lewat kantor desa, pamong hanya bertindak sebagai saksi.

Bahwa penyelesaian sengketa waris di luar Pengadilan Agama adalah Sengketa waris yang di selesaikan di kantor desa atau lewat musyawarah yang di lakukan oleh ahli waris secara syari'at agama dengan tujuan untuk kemaslahatan bersama dengan adanya suatu alasan tertentu, semisal kekawatiran terhadap ahli waris yang mungkin akan terjadi penganiayaan sesama ahli waris.

Pembagian harta waris di luar Pengadilan Agama sangat mudah, biaya ringan, tidak bolak-balik ke pengadilan, berbeda dengan penyelesaian di Pengadilan Agama, biaya banyak, tidak bisa segera di putuskan, sedangkan melalui kantor desa setempat bisa segera di putuskan, karena dari pihak ahli waris bisa segera datang memenuhi panggilan untuk melakukan kesepakatan yang tadinya sudah di setujui bersama.

Dalam penelitian ini, peneliti menemukan dokumen yang menerangkan tentang putusan penyelesaian sengketa waris berupa surat keterangan waris yang sudah disepakati bersama dan sudah ditandatangani di atas materai, mewawancarai beberapa nara sumber yang mengetahui secara langsung pelaksanaan penyelesaian sengketa waris di luar pengadilan yang terjadi di Desa Ngadi Kecamatan Mojo Kabupaten Kediri, penyelesaian sengketa waris ini terjadi karena adanya salah satu pihak yang kurang puas 
dengan penyelesaian pembagian harta waris yang dilakukan pada tahun 2008 lalu pada keluarga Muhyiddin, waktu itu Muhyiddin sakit dan dibawa ke Rumah Sakit untuk berobat, sedangkan biaya yang dikeluarkan ditanggung oleh Sarmini dengan syarat, tanah yang berada di Dusun Setonopundung seluas 360m sudah di beli oleh Sarmini dari total tanah seluruhnya $719 \mathrm{~m}$, dengan persetujuan ketiga saudara-saudaranya berdasarkan musyawarah, yang tanpa tanda bukti apapun.

Penyelesaian sengketa waris di luar Pengadilan Agama sangat menguntungkan, pertama tidak banyak mengeluarkan biaya, kedua sesuai dengan ketentuan agama, ketiga adanya rasa aman nyaman dan tidak takut dengan aparatnya, kalau di pengadilan ada rasa takut, begitu masuk langsung berfikir wah pengadilan, rasanya dengar katakata pengadilan gitu aja perasaannya sudah gak enak.

Penyelesaian sengketa waris di luar pengadilan dipahaminya, bahwa penyelesaian sengketa waris yang di lakukan dengan cara musyawarah oleh para pihak ahli waris dan di lanjutkan ke kantor desa untuk di mintakan surat persetujuan tentang pembagian waris yang di tandatangani di atas materai oleh para ahli waris.

Kalau saya simpel aja,dalam menyelesaikan pembagian waris lebih senang ke kantor desa dengan dibantu oleh pamong desa setempat daripada ke pengadilan, alasannya dari segala urusan apapun lebih mudah di kantor desa. namun demikian, saya kembalikan lagi ke saudara-saudara saya, mungkin dari saudara saya yang lain menginginkan untuk diselesaikan lewat Pengadilan Agama, ternyata mereka juga sependapat dengan saya artinya di selesaikan lewat musyawarah dan disaksikan supaya dicatat oleh pamong desa setempat.

Penyelesaian sengketa waris di luar Pengadilan Agama adalah penyelesaian yang dilakukan di luar Pengadilan Agama dengan jalan musyawarah keluarga dengan para ahli waris dengan minta bantuan kyai dan pamong desa setempat.

Dari beberapa penjelasan di atas sengketa waris di luar Pengadilan Agama dari hasil wawancara yang di lakukan oleh penulis dengan para informan dapat di simpulkan bahwa penyelesaian sengketa waris di luar Pengadilan Agama yang terjadi di Desa Ngadi Kecamatan Mojo Kabupaten Kediri, pada hakekatnya pelaksanaan proses sengketa waris di luar pengadilan agama tetap diminati oleh sebagian masyarakat desa meskipun kesepakatan para ahli waris kadang bisa diterima kadang tidak oleh para waris, namun keputusan tetap dilakukan setelah pihak ahli waris diberikan pemahaman 
tentang hak masing-masing ahli waris oleh aparat desa yang membantu proses penyelesaian tersebut, dan prosesinya disaksikan oleh aparat resmi pemerintah. Dengan demikian penyelesaian sengketa waris di luar pengadilan agama dianggap cukup, sehingga para penerima hak waris tidak perlu lagi mengajukan ke Pengadilan Agama, bahkan penyelesaian sengketa waris di luar Pengadilan Agama yang dilakukan di Kantor Desa oleh aparat desa setempat sangat membantu para ahli waris untuk mendapatkan haknya masing-masing. Karena didalam membantu penyelesaiannya terdapat unsur tolong menolong kepada masyarakat yang ingin menyelesaiakan permasalahan dengan cara tersebut.

\section{Praktek Penyelesaian Sengketa Waris Di Luar Pengadilan Agama Yang dilakukan masyarakat Desa Ngadi Kecamatan Mojo Kabupaten Kediri}

Penyelesaian sengketa harta warisan yang dilakukan oleh masyarakat Desa Ngadi terdapat 2 (dua) pelaksanaan yaitu penyelesaian harta warisan melalui musyawarah para pihak di rumah ahli waris dengan memanggil aparat desa setempat dan penyelesaian sengketa waris yang dilakukan di kantor Desa Ngadi.

Penyelesaian sengketa harta warisan yang dilakukan melalui musyawarah dengan para pihak ahli waris terjadi dalam bentuk sistem kemufakatan kekeluargaan yang dilakukan oleh para ahli waris berdasarkan hak kepemilikan individu terhadap harta warisan mereka, seperti contoh di bawah ini:

a. Penyelesaian sengketa waris yang dilakukan di salah satu rumah ahli waris:

Muhyidin yang telah meninggal pada tanggal 10 Mei 2004 di Desa Ngadi. Beliau meninggalkan harta warisan kepada ahli waris yang terdiri dari 2 (dua) anak perempuan dan 1 (satu) anak laki-laki, harta yang ditinggalkan terdiri atas rumah tempat tinggal di atas tanah $359 \mathrm{~m}^{2}$ dan sawah $360 \mathrm{~m}^{2}$. Harta tersebut dibagi oleh ahli waris melalui musyawarah berdasarkan status hak kepemilikan individu terhadap warisan mereka.

Musyawarah tersebut dilakukan oleh ahli waris berdasarkan musyawarah sehingga menghasilkan putusan: 4 (empat) ahli waris tersebut mendapatkan bagian masing-masing yaitu: Karnati mendapatkan rumah di atas tanah seluas $359 \mathrm{~m}^{2}$, kemudian sisa $360 \mathrm{~m}^{2}$ di bagi dengan rincian: 2 (dua) anak perempuan dan 1 (satu) anak laki-laki mendapatkan bagian masing-masing $120 \mathrm{~m}^{2}$ tanah sawah. Setelah para pihak setuju, mereka memanggil aparat Desa setempat untuk menguatkan putusan yang telah 
disepakati bersama oleh para ahli waris. Kesepakatan penyelesaian pembagian harta warisan melalui musyawarah keluarga ini bertujuan untuk menghindari penyelesaian sengketa waris lewat Pengadilan Agama.

b. Penyelesaian sengketa waris yang dilakukan di kantor desa

Sukarti almarhum, meninggal tanggal 4 September 2010 di Desa Ngadi, ia meninggalkan harta warisan kepada ahli waris yang terdiri atas 2 (dua) orang anak perempuan dan 3 (tiga) orang anak laki-laki. Harta warisan tersebut tanah pekarangan seluas $200 \mathrm{~m}^{2}$, dan rumah tempat tinggal di atas tanah seluas $50 \mathrm{~m}^{2}$, Harta tersebut dimusyawarahkan oleh ahli waris berkenaan dengan status pembagiannya. Namun, musyawarah itu tidak berhasil sehingga dilanjutkan ke Kantor Desa.

Musyawarah tersebut dilakukan ahli waris bersama Kepala Desa dan 2 (dua) orang tokoh masyarakat yaitu bapak Ismunandar dan bapak Saifulloh Hadi. Ketika acara dimulai Ibu Kades mempersilahkan para ahli waris untuk memusyawarahkan bagian masing-masing. Akan tetapi ahli waris masih tetap belum menemukan kesepakatan, namun setelah Ibu Kades dan 2 (dua) tokoh masyarakat memberikan nasihat bahwa pentingnya hukum kewarisan Islam untuk dilaksanakan mereka baru menemukan sebuah kesepakatan. Yaitu harta warisan dari ahli waris dibagi rata.

Sedangkan pada prakteknya, penyelesaian sengketa waris di luar pengadilan agama yang dilakukan di Desa Ngadi, peneliti dapat memaparkannya berdasarkan data yang diperoleh dari hasil wawancara dari pelaku sengketa waris antara lain:

Mereka melakukan sengketa waris di Desa Ngadi pada tanggal 15 september 2008 di Kantor Desa Ngadi Kecamatan Mojo Kabupaten Kediri yang dihadiri oleh pihak para ahli waris, kyai yang bernama Imam Ahmad dari Dusun Ngadi, dan aparat desa setempat.

Sebenarnya kami dalam melakukan penyelesaian waris, kami lakukan secara musyawarah di rumah, akan tetapi dari salah satu ahli waris ada yang mengusulkan ke kantor desa setempat, untuk menghindari manakala ada kesalahfahaman di antara ahli waris, agar tidak terjadi permasalahan di kemudian hari.

Sebelum bapak meninggal dunia, masih dalam keadaan sakit, yang membiayai pengobatan di Rumah Sakit adalah saya, selama dalam perawatan menghabiskan kurang lebih sekitar lima belas jutaan (15.000.000), karena sudah habis biaya banyak, maka bapak mengumpulkan semua anak-anaknya untuk memberitahukan, bahwa tanah yang 
terletak di setono pundung itu sudah dibeli oleh Sarmini dan mereka mengetahui semua, namun setelah bapak meninggal, ahirnya dilakukan pembagian waris tahun 2008. Disinilah timbulnya sengketa waris, karena ada salah satu ahli waris yang gak mau mengakui bahwa bapak tidak pernah menjual tanahnya, "dia bilang membantu biaya orang tua itu adalah kewjiban anak-anaknya" tapi kenyataannya saya sendiri yang keluar biaya.

Pada awalnya kami sudah sepakat untuk dilaksanakan di rumah dengan cara musyawarah, tetapi dari salah satu ahli waris ada yang tidak terima dengan bagiannya sehingga kami sepakat untuk melanjutkan ke kantor desa dengan tujuan minta bantuan pamong desa guna memberikan pemahaman tentang hak waris yang harus di terima oleh masing-masing ahli waris.

Dulu semasa bapak dan ibu masih hidup ada salah satu ahli waris kami yang pernah menjual tanah karena kebutuhan keluarganya sendiri, pada waktu itu ibu bilang kepada salah satu ahli waris (yang perna menjual tanah ), setelah kamu jual tanah ini, kelak kalau saya (ibu) meninggal dunia kamu dapat bagiannya tinggal sedikit karena sebagian sudah kamu jual sekarang, setelah ibu meninggal lalu dilakukan pembagian waris, tetapi adik saya masih tetap minta bagian yang sama, dengan alasan, dulu uang itu juga di pakai untuk kluarga ibu termasuk bapak, setelah itu permasalahan ini kami bawa ke kantor desa setempat, di sana oleh pak sekdes diberikan pemahaman tentang pembagian warisan, ahirnya adik bisa terima walaupun dengan wajah yang kliatannya tidak puas, trus dilakukan kesepakatan dan didatangani bersama.

Dengan demikian, secara realita bentuk penyelesaian sengketa waris di luar pengadilan yang terjadi di Desa Ngadi Kecamatan Mojo Kabupaten Kediri dapat di golongkan kedalam dua macam. Pertama: para ahli waris yang melakukan penyelesaian sengketa waris tersebut mengumpulkan atau menghadirkan pihak yang terkait dalam penyelesaian sengketa tersebut. Kedua, para ahli waris dalam menyelesaikan sengketa waris juga mendatangkan atau mendatangi pamong desa setempat dan tokoh agama guna meluruskan permasalahan dan keinginana para ahli waris tersebut.

Berdasarkan data yang ada, pada prakteknya penyelesaian sengketa waris yang terjadi di Desa Ngadi Kecamatan Mojo Kabupaten Kediri pada umumnya telah memenuhi ketentuan secara agama dan kebanyakan mereka menerima pembagian dengan cara tersebut. adapun proses penyelesaian sengketa waris di luar Pengadilan 
Agama yang biasa dilakukan oleh masyarakat Desa Ngadi sudah sesuai dengan syarat dan rukun Islam yaitu:

a. Rukun Kewarisan

1) Pewaris, yakni orang yang meninggal dunia, dan ahli warisnya berhak untuk mewarisi harta peninggalanya.

2) Ahli waris, yakni orang yang berhak menguasai atau menerima harta peninggalan pewaris dikarenakan ada ikatan kekerabatan, pernikahan dan wala'.

3) Harta warisan, yakni segala jenis benda atau kepemilikan yang ditinggalkan pewaris, baik berupa uang, tanah dan sebagainya.

b. Syarat-syarat Waris

1) Meninggalnya pewaris

Yang dimaksud meninggal disini ialah meninggal dunia secara hakiki (sejati), hukmi (menurut putusan hakim), maupun taqdiri (dugaan).

2) Masih hidupnya para ahli waris

Ketika seorang pewaris meninggal dunia maka ahli warisnya harus masih hidup.

Jika seorang pewaris dan ahli warisnya meninggal secara bersamaan maka ia tidak berhak untuk mendapatkan harta warisan lagi.

3) Diketahuinya posisi para ahli waris

Seseorang dapat mewarisi harta warisan jika sudah jelas diketahui hubungannya dengan pewaris. Seperti halnnya sebagai ibu, istri ataupun anak.

Secara umum, Para pelaku penyelesaian sengketa waris memberikan penjelasan bahwasannya penyelesaian sengketa waris di luar Pengadilan Agama adalah penyelesaian sengketa waris yang dilakukan dengan cara musyawarah yang telah terpenuhinya syarat dan rukun pembagian waris dengan diketahui oleh semua pihak yang bersengketa (para ahli waris) dan dikatahui oleh para saksi yaitu pamong desa, kyai dan masyarakat sekitar, hanya saja penyelesaian tersebut tidak melalui Pengadilan Agama atau tidak tercatat di Kantor Pejabat Pembuat Akta Tanah (PPAT). Selain itu yang membedakan penyelesaian sengketa waris di luar Pengadilan Agama yaitu oleh para pihak belum didaftarkan hasil putusan tersebut kepada Kantor Pengadilan Agama dan Pertanahan sebagai tindak lanjut penyelesaian yang telah disepakati, sehingga belum memiliki kekuatan hukum tetap. 
Dikarenakan akta perjanjian yang diterbitkan oleh kepala desa bukan termasuk akta notaris tanah. Bilamana para pihak telah membuat akta perjanjian dihadapan notaris maka sudah bisa memiliki kekuatan hukum yang mengikat.

Hukum waris Islam memiliki arti yang berbeda yaitu hukum yang mengatur tentang peralihan harta kekayaan yang ditinggalkan seseorang yang meninggal serta akibat dari para ahli warisnya. ${ }^{23}$ Begitu pula menurut perbandingan hukum kewarisan Islam dengan undang-undang hukum perdata yang isinya adalah merupakan himpunan aturan-aturan hukum yang mengatur tentang siapa ahli waris yang berhak mewarisi harta peninggalan dari orang yang meninggal dunia, bagaimana kedudukan ahli waris, berapa perolehan masing-masing secara adil dan sempurna. ${ }^{24}$

Sedangkan menurut Fuqoha mendefinisikan hukum kewarisan Islam sebagai suatu ilmu yang dengannya dapat kita ketahui, orang yang menerima pusaka, orang yang tidak menerima pusaka, serta kadar yang diterima tiap-tiap ahli waris dan cara membaginya, setelah dibayarkan seluruh tanggungan kewajiban almarhum. ${ }^{25}$

Sedangkan menurut hukum waris Islam, dalam penyelesaian sengketa waris ada tiga yaitu: Al-Quran, Al-Sunnah, dan Ijtihad. Namun masyarakat Desa Ngadi pada dasarnya hanya mengandalkan kesepakatan para ahli waris, karena lebih mengutamakan kerukunan keluarga, walaupun sudah tau bahwa dalam ketetapan hukum Islam yang sebenarnya pembagian waris itu juga harus berdasarkan hukum Islam.

Oleh karena itu, pemahaman sebagian masyarakat Desa Ngadi terhadap penyelesaian sengketa waris menurut Hukum Kewarisan Islam dan Kompilasi Hukum Islam sebagai sistem hukum yang mengatur masalah waris tidak menunjukkan sikap yang sebenarnya, karena fakta-fakta yang terjadi dalam pelaksanaan penyelesaian sengketa waris yang masih belum memenuhi ketentuan-ketentuan penyelesaian sengketa hukum kewarisan Islam maupun Hukum Waris menurut Kompilasi Hukum Islam (KHI) yang telah dibuat pedoman oleh Pengadilan Agama dalam menyelesaian persengketaan, bahkan ada yang bertentangan. Menurut hemat penulis, pemahaman dan sikap sebagian masyarakat Desa Ngadi dalam menyelesaikan sengketa waris lebih

\footnotetext{
${ }^{23}$ Efendi Perangin, Hukum Waris (Jakarta: Raja Grafindo Persada, 1997), 3.

${ }^{24}$ Idris Ramulyo, Perbandingan Hukum Kewarisan Islam dengan Kewarisan Kitab Undang-Undang Hukum Perdata. (Jakarta : Sinar Grafika, 2004), 84.

${ }^{25}$ Hasbi Ash-Shiddieqy, Fiqhul Mawaris (Jakarta : Bulan Bintang, 1973), 18.
} 
disebabkan oleh faktor rasional yang tidak mencerminkan pemahaman dan pengetahuan tentang sistem penyelesaian sengketa hukum kewarisan Islam dan penyelesaian waris menurut Kompilasi Hukum Islam (KHI) yang sebenarnya.

Selanjutnya, pemahaman sebagian masyarakat Desa Ngadi terhadap penyelesaian sengketa waris di luar pengadilan agama.Bahwa masyarakat Desa Ngadi dalam memahami penyelesaian sengketa waris masih cenderung memakai sistem hukum kebiasaan atau tradisi yang tidak membedakan bagian laki-laki dan perempuan. Meskipun mereka mengatakan bahwa sistem hukum kewarisan Islam adalah hukum yang mengatur terhadap harta warisan yang sesuai menurut syariat Islam.

Mengenai praktek penyelesaian sengketa waris di luar Pengadilan Agama yang berkembang dalam masyarakat Desa Ngadi Kecamatan Mojo Kabupaten Kediri menurut hemat penulis berdasarkan informasi yang didapatkan dari hasil wawancara dengan beberapa informan, pada praktek penyelesaiannya mereka telah mengadakan musyawarah antara para ahli waris, kalau semua para ahli waris sudah sepakat, maka mereka datang ke kantor desa untuk mengadakan pencatatan dengan disaksikan oleh pamong desa dan kyai setempat untuk menjadi saksi dalam penyelesaian pembagian waris tersebut atau pihak ahli waris mengundang aparat desa dan kyai setempat untuk datang ke rumah ahli waris.

Kemudian dalam musyawarah keluarga masih belum bisa diputuskan, maka mereka mendatangkan kyai lebih dahulu untuk memberikan penjelasan kepada para ahli waris tentang haknya masing-masing, setelah mereka memahami bagiannya masingmasing, baru dilanjtkan ke kantor desa untuk melakukan pencatatan sekaligus minta bantuan pamong utuk jadi saksi dalam pembagian waris yang sudah memenuhi syarat dan rukunnya pembagian harta waris tersebut, penyelesaian sengketa waris semacam ini, oleh masyarakat desa ngadi sudah dianggap sah karena sudah memenuhi rukun dan syarat yang telah disepakati para ulama, walaupun tidak melalui Pengadilan Agama yang mengharuskan adanya pencatatan yang sah menurut peraturan pemerintah.

Di samping itu, terdapat faktor-faktor tambahan yang mendasar hingga memberi dorongan kepada masyarakat Desa Ngadi Kecamatan Mojo Kabupaten Kediri untuk melakukan penyelesaian sengketa waris di luar Pengadilan Agama. Diantara faktorfaktor tambahan yang mendorong terjadinya penyelesaian sengketa waris di luar Pengadilan Agama di Desa Ngadi Kecamatan Mojo Kabupaten Kediri adalah sebagai 
berikut: Karena adanya aturan Pengadilan Agama yang menyangkut persyaratan administratif dalam hal proses pengurusan sengketa waris begitu rumit dan berbelitbelit, juga terkait dengan ahli waris "bahwa ahli waris yang masih hidup tetapi sudah tidak mampu untuk datang ke Pengadilan Agama, maka prosespun tidak akan berjalan dengan lancar, karena adanya salah satu ahli waris yang tidak hadir, dengan demikian proses ditunda, terlalu lama menunggu untuk mendapatkan surat panggilan padahal pengajuan berkas sudah cukup, harus mempersiapkan persyaratan-persyaratan untuk pengajuan waris, belum nanti kalau salah satu ahli waris tidak bisa hadir karena sudah tua atau sakit, belum lagi para ahli waris tidak bisa hadir secara bersamaan, sehingga harus mencari waktu yang pas untuk bisa datang ke Pengadilan Agama.

Secara teoritis, faktor-faktor tambahan di atas yang menyebabkan terjadinya penyelesaian sengketa waris di Desa Ngadi, karena untuk menghindari prosedur administrasi penyelesaian sengketa waris yang terlalu lama dan berbelit-belit, keinginan untuk segera terlepes dari sengketa tersebut, faktor psikologi yang terbebani karena merasa malu dengan tetengga, faktor ekonomi yang tidak mampu untuk biaya memenuhi kelengkapan administrasi yang bagi mereka tidak sedikit, dan faktor tradisi juga agama yang masih kental berkembang di masyarakat. Sedangkan penyelesaian sengketa waris di luar pengadilan agama sangat diminati oleh masyarakat Desa Ngadi Kecamatan Mojo Kabupaten Kediri, mereka merasa "senang" karena proses penyelesaian sengketa waris di luar Pengadilan Agama lebih cepat tanpa berbelit-belit dan tidak membutuhkan waktu yang lama, dapat mengurangi beban para ahli waris, mereka juga bisa segera mengetahui keputusan sengketa yang ada dalam keluarganya, sehingga mereka bisa segera menggunakan haknya msing-masing.

Dengan demikian, sejalan dengan perkembangan ilmu hukum saat ini pencatatan waris dan akta tanahnya sangatlah diperlukan karena mempunyai kemaslahatan umum (mashlahah mursalah) demi untuk kesejahteraan hidup bersama saudara dan keluarga. Untuk itu, sudah seharusnya bagi semua pihak terutama bagi pemerintah untuk meminimalisir biaya proses sengketa waris dan meningkatkan pelayanan terhadap masyarakat, sehingga bisa mengarahkan masyarakat agar tidak takut lagi untuk memproses melalui prosedur. Dengan begitu tidak akan ada lagi permasalahanpermasalahan yang tidak jelas asal-usulnya. 
Dalam masyarakat juga perlu sosialisasi konkrit, menjelaskan hakekat pembagian waris bagi semua pihak, bahwa pembagian warisan bukan sekedar sarana untuk mendapatkan bagian harta benda saja,tetapi lebih dari itu dimana butuh adanya tanggung jawab baik di dunia maupun di akhirat.

Termasuk para akademissi juga seharusnya secara proaktif mensosialisasikan betapa pentingnya dalam penyelesaian sengketa waris bisa dilakukan melalui Pengadilan Agama (PA), dengan berbagai pendekatan yang mereka lakukan dalam bentuk tulisan, artikel, buku, diskusi ataupun seminar. Semakin banyaknya masyarakat yang membaca dan mengetahui akan realitas penyelesaian sengketa waris di masyarakat, maka mereka akan bisa memilih untuk memproses lewat pengadilan agama.

Pembagian waris sering kali menjadi masalah di dalam keluarga, mulai jaman dahulu hingga sekarang masih ada saja ahli waris yang tidak mengerti tentang aturanaturan dalam pembagian harta warisan, atau memang mereka tidak mau tau tentang aturan-aturan tersebut, oleh sebab itu, Para Dai, Orator ataupun Muballigh dengan kepiawaiannya diharapkan bisa menarik massa dari berbagai kalangan, yang seharusnya turut dilibatkan untuk menggerakkan masyarakat untuk meninggalkan kebiasaankebiasaan yang bisa mengakibatkan perpecahan keluarga dan saudara-saudaranya sendiri, dalam hal ini adalah masalah waris.

\section{Faktor Penyebab Terjadinya Penyelesaian Sengketa Waris Di Luar Pengadilan Agama Yang Dilakukan masyarakat Desa Ngadi Kecamatan Mojo Kabupaten}

\section{Kediri}

Menurut ahli waris Sarmini menanggapi masalah penyebab mereka sampai melakukan penyelesaian sengketa waris di luar Pengadilan Agama adalah karena adanya aturan Pengadilan Agama yang menyangkut persyaratan administratif dalam hal proses pengurusan sengketa waris begitu rumit dan berbelit-belit, juga terkait dengan ahli waris seperti yang disampaikan Sarmini, yang menyatakan "bahwa ahli waris yang dia masih hidup tapi sudah tidak mampu untuk datang ke Pengadilan Agama, maka prosespun tidak akan berjalan dengan lancar, karena adanya salah satu ahli waris yang tidak hadir, dengan demikian proses ditunda dan kembali lagi ke Kanto Pengadilan Agama setelah semua ahli waris sudah betul-betul siap". maka dari itu mereka 
melakukan penyelesaian sengketa waris ke kantor desa setempat untuk mendapatkan pelayanan yang mudah.

Ada juga karena faktor terlalu lama menunggu untuk mendapatkan surat panggilan padahal pengajuan berkas sudah cukup. Seperti apa yang telah di sampaikan oleh Sarmilah " karena saya belum pernah ngurus masalah waris ke Pengadilan Agama sendiri” jadi hanya denger-denger, harus mempersiapkan persyaratan-persyaratan untuk pengajuan waris, belum nanti kalau salah satu ahli waris tidak bisa hadir karena sudah tua atau sakit, trus para ahli waris tidak bisa hadir secara bersamaan, sehingga harus mencari waktu yang pas untuk bisa datang ke Pengadilan Agama, dan kita harus menunggu lama dalam proses pemanggilan, kan ribet jadinya".

Sedangkan yang menyebabkan Sarmilah melakukan penyelesaian sengketa waris di luar Pengadilan Agama adalah karena pengaruh dari tradisi yang kuat dan masih kental yang sudah mengakar hingga menjadi budaya bagi masyarakat desa yang masih bersifat konservatif (kolot, atau kebiasaan) dalam mempertahankan sesuatu yang dianggap benar dan merupakan tradisi yang dipakai oleh kebanyakan warga Desa Ngadi atau mengikuti jejak para leluhur.

Bahwa masih ada masyarakat yang apabila mempunyai urusan waris, mereka mengundang aparat desa setempat untuk datang ke rumah para ahli waris untuk dimintai bantuan menyelesaikan sengketa waris yang ada pada keluarganya dengan alasan ada yang tidah bisa jalan atau dengan alasan yang lain, bahkan masih ada yang menganggap dan meyakini bahwasanya warisan apapun apabila dalam pembagiannya tidak dengan cara yang baik, maka akan berakibat buruk bagi yang menyalah gunakan barang warisan tersebut.

Sehingga bisa diartikan bahwasanya penyelesaian sengketa waris yang dilakukan di luar Pengadilan Agama hanyalah untuk mensiasati apa yang menjadi ketentuan tradisi atau budaya dan kebiasaan yang berkembang di masyarakat atau sebagai solusi untuk mengantisipasi terjadinya konflik keluarga antara ahli warais yang tidak menghendaki penyelesain waris melalui Pengadilan Agama.

Sebenarnya saya malu dengan keluarga yang lain, juga sama tetangga, terlebih pada saat saudara berkupul, hanya gara-gara permasalahan pembagian waris saja kok jadi diributkan, sehingga bisa muncul kata-kata dari tetangga, jaman sekarang kok masih ad yang berebut warisan. Bahwa pembagian waris itu tidak perlu diributkan atau 
diperdebatkan, karena harta warisan itu bisa berdampak positif juga bisa berdampak negatif, Positifnya bila harta warisan itu di bagi dengan cara baik-baik dan digunakan dengan baik, maka harta warisan itu akan bermanfaat bagi kelanjutan hidup ahli waris, sedangkan Negatifnya bila cara pembagiannya dengan cara tidak baik (dengan kecurangan atau serakah) dan disalah gunakan, maka harta tersebut tidak akan Barokah sehingga akan membuat kesengsaraan bagi kehidupan selanjutnya.

Di samping itu juga, masyarakat Desa Ngadi yang memiliki idiologi agama yang kuat, mereka memahamkan bahwasannya menurut syariat Islam, pembagian harta waris dianggap sah apabila syarat dan rukunnya telah terpenuhi dan mereka mengetahui bagiannya masing-masing.

Sebenarnya yang mendasari masyarakat desa sini melakukan penyelesaian sengketa waris diluar Pengadilan Agama adalah disebabkan karena berbagai alasan, di antaranya banyak pihak ahli waris khawatir jika diselesaikan melaui Pengadilan Agama akan tambah rumit, kemudian dengan alasan lebih baik diselesaikan dengan cara kekeluaargaan atau musyawaroh, di mana para ahli waris sudah saling sepakat untuk bagiannya masing-masing yang sudah di sepakati bersama dan di saksikan oleh beberapa saksi, ada juga karena alasan bahwa ada salah satu anggota ahli waris yang tidak bisa diatur (serakah), sehingga untuk menyelesaikan permasalahan waris tersebut mereka meminta saya untuk memeberikan penjelasan kepada salah satu ahli waris yang tidak mau di ajak musyawaroh, ada juga karena alasan yang lainnya dan semua itu kami layani ketika ahli waris minta tolang untuk dibantu dalam menuntaskan masalah waris dikeluarganya, tetapi dengan syarat mereka benar-benar sepakat untuk menerima penjelasan tentang pembagian harta waris. Disamping itu saya pikir dengan membantu permasalahan sengketa waris yang dihadapi orang lain itu merupakan hal yang baik, karna itu termasuk saling tolong-menolong.

Dengan demikian, berdasarkan data yang diperoleh dari ahli waris dan masyarakat yang ada di wilayah Desa Ngadi yang telah penulis paparkan, dapat disimpulkan bahwa adanya penyelesaian waris diluar pengadilan agama di Desa Ngadi Kecamatan Mojo Kabupaten Kediri muncul dari beberapa faktor yang berbeda-beda sesuai dengan situasi, kondisi dan pemikiran dari keluarga itu sendiri. Di samping sebagai langkah yang cepat, aman dan praktis, menurut mereka juga bertujuan untuk menyelamatkan diri dari masalah hukum yang ada di lingkungan Pengadilan Agama, 
serta adanya dukungan dari aparat pemerintah desa setempat dengan pertimbangan demi kemaslahatan dan tolong-menolong dengan syarat adanya kejelasan atau kesanggupan untuk memenuhi persyaratan waris baik secara administratif maupun syari'at agama, juga terbentur dengan beberapa alasan sehinga mereka memilih menyelesaikan waris diluar Pengadilan Agama.

Di antara faktor-faktor tersebut antara lain, faktor benturan dengan aturan hukum positif semisal terlalu lamanya proses waris melalui pengadilan agama (PA), faktor tradisi atau kebiasaan mayarakat yang menggunakan cara sederhana, faktor psikologi semisal adanya keinginan yang kuat untuk segera memproses sengketa waris ini lewat kantor desa agar lebih jelas, juga karna faktor ideologi agama yang masih berkembang kuat di masyarakat sehingga menjadikan pemahaman tentang makna pentingnya sebuah pembagian harta waris yang sah melalui Pengadilan Agama masih minim dan kurang dapat mereka pahami secara mendalam, yang mereka pahami selama ini, proses waris dianggap sah apabila syarat dan rukunnya telah terpenuhi dan mereka mengetahui bagiannya masing-masing.

Dengan demikian, nilai efektifitas penyelesaian sengketa waris pada masyarakat Desa Ngadi Kecamatan Mojo Kabupaten Kediri adalah:

a. Nilai efektifitas Penyelesaian Sengketa Waris Pada Masyarakat Desa Ngadi Kecamatan Mojo Kabupaten Kediri

Berdasarkan data yang diperoleh dari ahli waris dan masyarakat yang ada di wilayah Desa Ngadi yang telah penulis paparkan, bahwa adanya penyelesaian waris diluar Pengadilan Agama di Desa Ngadi Kecamatan Mojo Kabupaten Kediri menurut pemahaman mereka adalah penyelesaian sengketa waris diluar Pengadilan Agama yang dilakukan dengan cara musyawarah yang dihadiri oleh para ahli waris, para pamong desa dan kyai setempat. pada hakeketnya penyelesaian dengan cara tersebut sampai saat ini masih banyak diminati oleh masyarakat Desa Ngadi, karena menurut mereka usaha yang diberikan oleh pamong dan kyai tersbut sangat membantu dalam proses persengketaan waris yang ada pada keluarga para ahli waris, dengan demikian penyelesaian sengketa waris diluar Pengadilan Agama dianggap cukup dan sah menurut mereka, sehingga para ahli waris tidak perlu lagi datang ke Pengadilan Agama untuk penyelesaian sengketa waris tersebut.

b. Nilai Religius Masyarakat Desa Ngadi Dalam Penyelesaian Sengketa Waris 
Penyelesaian sengketa waris di luar pengadilan agama yang dilakukan di Desa Ngadi, peneliti dapat memaparkannya berdasarkan data yang diperoleh dari hasil wawancara dengan para informan sekaligus pelaku sengketa waris, bahwa praktek penyelesaian sengketa warisan yang dilakukan oleh masyarakat Desa Ngadi secara Agama sudah memenuhi syarat dan rukunnya, di dalam praktek pembagian waris tersebut ada yang memakai cara 1 (satu) banding 2 (dua), ada juga yang memakai cara bagi rata setelah mengetahui bagiannya masing-masing, karena di dalam Norma Agama tidak terdapat sanksi yang diberikan, bilamana salah satu pihak melanggar kesepakatan dalam pembagian waris, semisal, dalam hal warisan tanah, bahwa proses penyelesaian sengketa waris sudah disepakati bersama, namun setelah ada kesepakatan dan dilakukan pematokan atas tanah warisan tersebut, ada salah satu ahli waris yang merasa kurang bagiannya, begitu para pamong yang membantu pematokan pergi, salah satu ahli waris itupun langsung memindah patok tersebut, dengan tujuan dia akan mendapatkan lebih banyak bagiannya. Dengan adanya ulah salah satu ahli waris yang melanggar kesepakatan tersebut, maka tidak ada sanksi apapun dari pamong maupun Agama, hanya saja dia akan mempertanggungjawabkan perbuatannya di akhirat kelak. Di dalam pelaksanaan sengketa waris di desa Ngadi terdapat 2 (dua) pelaksanaan yaitu penyelesaian sengketa waris melalui musyawarah di rumah ahli waris dengan menghadirkan pamong desa dan kyai setempat ada juga dalam penyelesaian sengketa waris yang dilakukan melalui kantor desa setempat dan disaksikan oleh pamong desa dan kyai.

c. Nilai Lokalitas Kultural Masyarakat Desa Ngadi Kecamatan Mojo Kabupaten Kediri

Berdasarkan data yang diperoleh dari informan dan masyarakat yang ada di Desa Ngadi yang telah penulis paparkan, bahwa adanya penyelesaian waris diluar pengadilan agama di Desa Ngadi Kecamatan Mojo Kabupaten Kediri muncul dari beberapa faktor yang berbeda-beda sesuai dengan situasi, kondisi dan pemikiran dari keluarga itu sendiri. Di samping sebagai langkah yang cepat, aman dan praktis, menurut mereka juga bertujuan untuk menyelamatkan diri dari masalah hukum yang ada di lingkungan Pengadilan Agama, serta adanya dukungan dari aparat pemerintah desa setempat dengan pertimbangan demi kemaslahatan dan tolong-menolong dengan syarat 
adanya kejelasan atau kesanggupan untuk memenuhi persyaratan waris baik secara administratif maupun syari'at agama.

d. Lokalitas Historis Masyarakat Desa Ngadi

Menurut salah satu informan, bahwa pada suatu era, berawal dari seorang kyai sepuh Desa Ngadi, yaitu kyai Suparlan (almrhum) yang meninggal pada hari Jumat Kliwon tanggal 24 oktober 2008. Dia melakukan tahkim pada masyarakatnya yang bersengketa karena tidak tahu tentang bagaimana cara proses pembagian warisan yang benar, sehingga dengan permasalahan tersebut terjadilah permusuhan antara ahli waris, Selanjutnya mereka memanggil kyai suparlan untuk membantu sebagai mediator persengketaan dan sekaligus konsultan hukum, pada akhirnya sengketa tersebut selesai dengan cara musyawarah, saling mengerti satu sama lain.

Dengan demikian masyarakat Desa Ngadi sampai sekarang masih banyak yang melakukan penyelesaian proses sengketa waris dihadapan kyai, yang disaksikan dan dicatat oleh pamong Desa di Balai Desa, ada juga terbentur dengan beberapa alasan sehinga mereka memilih menyelesaikan waris diluar Pengadilan Agama.

Maka dari itu di jelaskan oleh informan yang sama, sampai saat ini mereka belum mempunyai akta tanah sebagai bukti bahwa waris tersebut sudah dibagi, dan mereka akan kerepotan kalau dikemudian hari ada yang menggugat (anak dan cucu), mereka harus mulai dari awal lagi. Sebab sampai sekarang keputusan yang dihasilkan dari penyelesaian sengketa waris di luar Pengadilan Agama tidak mempunyai surat akta tanah atau sertifikat tanah sehingga ada kemungkinan tidak mendapatkan perlindungan hukum negara yang kuat karena mereka belum mendaftarkan ke Kantor Pertanahan, namun apabila dikemudian hari ada permasalahan lagi mereka sepakat untuk melanjutkan dan menyelesaikan persengketaan ke Pengadilan Agama.

Hal-hal tersebut di atas adalah sebagai gambaran yang timbul akibat penyelesaian waris diluar Pengadilan Agama yang terjadi di Desa Ngadi Kecamatan Mojo Kabupaten Kediri yang ada baik dan buruknya, khususnya bagi para ahli waris dan orang lain. Dan berdasarkan observasi langsung kelokasi penelitian, dari para informan dan kedelapan pelaku pembagian waris yang telah disebutkan di atas, semuanya belum ada yang melanjutkan ke Pengadilan Agama, walaupun ada salah satu masalah yang sampai saat ini belum bisa terselasaikan. 


\section{Kesimpulan dan Saran}

\section{Kesimpulan}

a. Proses penyelesaian sengketa waris di desa Ngadi Kecamatan Mojo kabupaten Kediri dilakukan dengan cara musyawarah keluarga yang berlanjut sampai ke kantor desa yang di hadiri oleh pamong desa dan kyai setempat untuk mendapat saran hukum dan petunjuk administratif pertanahan. Sedangkan prakteknya penyelesaian sengketa waris di luar Pengadilan Agama yang terjadi di Desa Ngadi dilakukan secara mufakat yang dihadiri oleh para ahli waris, sekretaris desa, kaur pemerintahan, kaur umum, kepala dusun dan seorang kyai.

b. Yang melatar belakangi penyelesaian sengketa waris yang dilakukan di Desa Ngadi Kecamatan Mojo Kabupaten Kediri adalah disebabkan karena adanya beberapa faktor, antara lain: faktor benturan dengan aturan hukum positif, faktor ekonomi, faktor psikologi, faktor sosial dan juga faktor tradisi dan agama yang masih berkembang kuat di masyarakat.

\section{Saran}

a. Bagi masyarakat, khususnya para ahli waris sebaiknya berfikir dahulu sebelum terlanjur dan menyesal dikemudian hari manakala ada salah satu ahli waris yang menggugat kembali karena tidak puas dengan keputusan yang pernah di sepakati bersama dahulu, karena itu akan merugikan diri masing-masing ahli waris. Bagaimapun penyelesaian sengketa waris akan lebih sempurna dan kuat jika dilegalkan secara hukum agama dan hukum negara.

b. Bagi para kyai, harus mampu memberikan masukan dan pengarahan yang berkaitan dengan pembagian warisan, bahwa penyelesaian dalam sengketa waris lebih baik berpedoman atas dasar kekeluargaan, sebab kyai adalah seorang figur yang disegani dan dihormati oleh masyarakatnya, sehingga masyarakat akan lebih memperhatikan apa yang disarankan oleh kyainya.

c. Pemerintah ikut berkewajiban untuk mensosialisasikan aturan-aturan yang ada dengan cara mengikis habis adanya biaya-biaya siluman yang membengkak dari biaya resmi pengajuan perdata waris. Di sanping itu, perlu adanya upaya untuk meningkatkan pelayanan, khususnya dalam proses waris yang telah dilakukan oleh sebagian masyarakat dengan cara memberikan kemudahan bagi mereka agar segera 
melaporkan permasalahan tersebut untuk segera membuat akta tanah dengan biaya ringan dan proses yang mudah.

d. Bagi pembaca, khususnya peneliti yang akan datang diharapkan mampu mengadakan penelitian yang lebih detail lagi terkait dengan masalah persengketaan waris sehingga bisa dibuat sebagai bahan pertimbangan bagi masyarakat maupun pihak pemerintah di dalam mengambil kebijakan terhadap para pelaku pembagian warisan. 


\section{Daftar Pustaka}

Abdurrahman, Kompilasi Hukum Islam di Indonesia. Jakarta: Akademika Pressindo, 2007.

Anshori, Abdul Ghofur, Filsafat Hukum Kewarisan Islam. Yogyakarta: UII Press, 2005.

Arikunto, Suharsimi, Prosedur Penelitian. Jakarta: Rineka Cipta, 1996.

Ash-Shiddieqy, Hasbi, Fiqhul Mawaris. Jakarta: Bulan Bintang, 1973.

Budiono, Rahmad, Pembaharuan Hukum Kewarisan Islam di Indonesia. Bandung: PT. Citra Aditya Bakti, 1999.

Bungin, Burhan, Analisis Data Penelitian Kualitatif. Jakarta: PT. Raja Grafindo Persada, 2003.

Hadikusuma, Hilman, Hukum Waris Adat. Bandung: Citra Aditya Bakti, 2003.

J. Moleong, Lexi, Metode Penelitian Kualitatif. Bandung: PT Remaja Rosda Karya Offset, 2002.

Mulyadi, Kartin Dan Widjaja Gunawan, Hak-Hak Atas Tanah. Jakarta: Kencana Prenada Media Group Press, 2008.

Perangin, Efendi, Hukum Waris. Jakarta: Raja Grafindo Persada, 1997.

Saiban, Kasui. Hukum Waris Islam. Malang: UM Press, 2007.

Usman, Suparman, Ikhtisar Hukum Waris menurut Kitab Undang-undang Hukum Perdata. BW. Serang: Darul Ulum Press, 1993.

Weldan, Ahmad Taufiq, Huda Dimyati, Metodologi Studi Islam. Malang: Bayumedia Publishing, 2004. 